\title{
PENTINGNYA MELAKUKAN PEMETAAN DAN SEGMEN PASAR DALAM PENJUALAN PRODUK KOPERASI MAESTRO 2012
}

\author{
Gojali Supiandi ${ }^{1}$, Isep Amas Priatna², Udin Saprudin², Lucia Maduningtias', \\ Eman Suleman ${ }^{5}$ \\ Universitas Pamulang \\ Email: dosen01567@unpam.ac.id
}

\begin{abstract}
This community service activity aims to transfer knowledge on how to make market segmentation for members of the Maestro 2012 South Tangerang Cooperative in order to increase sales of products and services offered by utilizing knowledge and applications. The method used is in the form of material delivery in the form of presentation theory and product marketing practices. The activity method used is to collaborate with the Maestro 2012 Cooperative by analyzing the problems in that place so that they can provide the right solution in motivating members who are SME businessmen under the auspices of the Maestro 2012 Cooperative. After the analysis, we provide training in the form of material and practice which aims to develop the ability to increase marketing for members of the 2012 Maestro Cooperative UKM, South Tangerang
\end{abstract}

Keywords: Market Segmentation and Training.

\begin{abstract}
Abstrak
Kegiatan pegabdian kepada masyarakat ini bertujuan untuk mentransfer pengetahuan bagaimana membuat segmentasi pasar bagi anggota Koperasi Maestro 2012 Tangerang Selatan agar dapat meningkatkan penjualan produk maupun jasa yang ditawarkan dengan memanfaatkan ilmu dan aplikasi Adapun metode yang dilakukan berupa penyampian materi dalam bentuk teori presentasi dan praktik mamasarkan produk. Metode kegiatan yang digunakan adalah bekerjasama dengan Koperasi Maestro 2012 dengan memganalisis pemasalahan yang ada di tempat tersebut sehingga dapat memberikan solusi yang tepat dalam memotivasi anggota yang adalah pelaku bisnis UKM dibawah naungan Koperasi Maestro 2012. Setelah di analisis maka kami memberikan pelatihan dalam bentuk materi dan praktek yang bertujuan mengembangkan kemampuan untuk meningkatkan pemasaran bagi para anggota UKM Koperasi Maestro 2012 Tangerang Selatan
\end{abstract}

Kata Kunci: Segmentasi Pasar dan Pelatihan 


\section{A. PENDAHULUAN}

Dalam kehidupan modern sekarang ini, koperasi memiliki peranan sangat penting dalam meningkatkan pertumbuhan dan kestabilan perekonomian suatu negara. Karena semua sektor usaha sangat membutuhkan koperasi sebagai wadah untuk melakukan transaksi keuangannya. Oleh karena itu, koperasi di Indonesia harus mempunyai sistem dan pengawasan koperasi yang kuat.

Strategi pemasaran mempunyai peranan yang sangat penting untuk keberhasilan usaha perusahaan/koperasi pada umumnya dan bidang pemasaran pada khususnya. Disamping itu strategi pemasaran yang ditetapkan harus ditinjau dan dikembangkan sesuai dengan perkembangan pasar dan lingkungan pasar. Dengan demikian strategi pemasaran dapat memberikan gambaran dengan jelas dan terarah tentang apa yang perlu dilakukan perusahaan dalam menggunakan setiap kesempatan atau peluang.

Menurut Kotler dan Keller (2016:27) menyatakan marketing is the activity, set of institutions, and processes for creating, communicating, delivering, and exchanging offerings that value for customers, clients, partners, and society at large.Definisi tersebut mendefinisikan bahwa. Pemasaran adalah kegiatan, mengatur lembaga, dan proses untuk menciptakan, mengkomunikasikan, menyampaikan, dan bertukar penawaran yang nilai bagi pelanggan, klien, mitra, dan masyarakat pada umumnya.Menurut Kotler dan Keller (2016:27),Marketing is a sociental proces by which individuals and groups obtain what they need and want through creating, offering, and freering, and freely exchanging products and services of value with others.Definisi tersebut mendefinisikan bahwa. Pemasaran adalah proses sosial dimana individu dan kelompok mendapatkan apa yang mereka butuhkan dan inginkan melalui penciptaan, penawaran, dan freering, dan bebas bertukar produk dan jasa dari nilai dengan lain

Pasar terdiri dari banyak pembeli dan pembeli dalam banyak hal, baik dalam motif, perilaku, maupun kebiasaan pembelian. Perbedaan tersebut menunjukkan bahwa pasar suatu produk tidak homogen, tetapi heterogen. Hal inilah yang mendorong perusahaan melakukan segmentasi pasar. Segmentasi merupakan pengelompokkan pembeli dalam suatu pasar yang memiliki kebutuhan dan tingkah laku yang sama. Segmentasi merupakan unsur pertama strategi pemasaran. Menurut Hermawan Kartajaya (2003), segmentasi berarti melihat pasar secara kreatif.

Terdapat 4 pola dasar dalam menentukan segmentasi pasar, yaitu segmentasi geografis, segmentasi demografi, segmentasi psikografi, dan segmentasi tingkah laku. Segmentasi geografis berarti mengelompokkan konsumen berdasarkan tempat, lokasi, dan daerah. Segmentasi demografi yaitu membagi pasar berdasarkan jenis kelamin, umur, status perkawinan, jumlah keluarga, umur anak, pendapatan, jabatan, lokasi geografis, mobilitas, kepemilikan rumah, agama, dan ras atau kebangsaan. Sedangkan segmentasi psikografi yaitu membagi pasar menjadi suatu kelompok yang berbeda berdasarkan pada karakteristik kelas sosial, gaya hidup dan karakteristik kepribadian. Dan yang terakhir yaitu segmentasi tingkah laku merupakan pengelompokkan konsumen berdasarkan pengetahuan, sikap, penggunaan atau reaksi mereka terhadap suatu produk yang diukur dengan menggunakan indikatorindikator tertentu.

Dalam menentukan segmentasi pasar yang tepat diperlukan adanya pengidentifikasian dan pemanfaatan peluang yang muncul dipasar. Pertama, peran segmentasi dapat memungkinkan pemasar untuk lebih fokus. Kedua, segmentasi memungkinkan pemasar mendapatkan insight mengenai peta kompetisi dan sisi pasar. Ketiga, segmentasi merupakan basis untuk memudahkan pasar mempersiapkan tahap berikutnya. Keempat, segmentasi 
merupakan faktor kunci mengalahkan pesaing dengan memandang pasar dari sudut yang unik dan cara yang berbeda.

Dengan beragamnya jenis mata pencaharian masyarakat Tangerang Selatan, maka Koperasi Maestro 2012 harus dengan benar dan tepat dalam menentukan segmentasi pasar agar tidak terjadi kesalahan. Karena segmentasi pasar ini sangat berpengaruh terhadap kelangsungan berjalannya usaha Koperasi Maestro 2012. Pentingnya dalam menentukan segmentasi pasar dengan tepat yaitu guna untuk menentukan segmen mana yang akan menjadi sasaran pasar dan mengetahui segmen mana yang berpotensial lalu kemudian koperasi Maestro 2012 dapat mengavaluasi target atau segmen pasar yang telah dipilihnya untuk menentukan strategi pemasaran yang tepat agar menjadi lebih baik dan terarah dengan segmentasi pasar yang sudah ditentukan. Setelah menjadikan strategi pemasaran menjadi lebih terarah, selanjutnya juga untuk keberlangsungan usaha bank untuk mendapatkan nasabah yang berpotensial dan juga untuk mendapatkan keuntungan.

Berdasarkan survey yang telah dilakukan diketahui dari data yang didapat bahwa mayoritas anggota Koperasi Maestro 2012 sebagian besar adalah anggota berwirausaha UMKM dan berwirausaha P3. Hal ini disebabkan segmentasi pasar yang dilakukan oleh Koperasi Maestro 2012 fokus kepada segmen konsumsi golongan penghasilan tetap lainnya. Dan juga meningkatkan kerjasama strategis dalam penjualan produk-produk UMKM dan produk P3 dengan cara melakukan pemetaan terhadap lembaga pelatihan, atau instansi pemerintah.

Yang termasuk dalam anggota golongan berpenghasilan tetap itu yaitu seperti wirausaha umkm dan wirausaha P3. Sedangkan yang termasuk dalam anggota golongan atau anggota non golongan berpenghasilan tetap yaitu wiraswasta guna untuk pemenuhan modal usaha kecil dan mikro. Segmentasi pasar yang dilakukan atau digunakan oleh koperasi maestro 2012 adalah segmentasi demografi dengan berfokus pada jenis wirausaha dari anggota tersebut, Koperasi Maestro 2012 berfokus pada anggota golongan berpenghasilan tetap.

\section{B. METODE PELAKSANAAN}

Metode kegiatan yang digunakan adalah bekerjasama dengan Koperasi Maestro 2012 Pamulang, Tangerang Selatan-Banten dan mencari pemasalahan yang ada di tempat tersebut melalui survey awal sampai pada tahap penetapan lokasi dan sasaran sehingga dapat memberikan solusi yang tepat dalam memotivasi anggota Koperasi Maestro 2012 dalam menentukan target pasar. Menurut IA Priatna et al (2020) bahwa solusi yang tepat akan didapat setelah dilakukan survey yang mendalam. Setelah di analisis maka kami memberikan pelatihan dalam bentuk materi dan praktek dalam mengembangkan kemampuan dalam pemasaran produk kepada para anggota Koperasi Maestro 2012 Pamulang, Tangerang Selatan. Adapun jadwal pengabdian masyarakat yang sudah disepakati antara Tim PKM Universitas Pamulang dengan Koperasi Maestro 2012 Pamulang, Tangerang Selatan .yaitu pada tanggal 17 Oktober di Koperasi Maestro 2012 Pamulang, Tangerang Selatan.

\section{HASIL DAN PEMBAHASAN}

Setiap lembaga keuangan koperasi termasuk koperasi maestro ketika ingin memutuskan untuk masuk ke pasar yang luas, ia menyadari bahwasannya ia tidak dapat begitu saja masuk dan melayani semua orang/calon nasabah yang berada di dalam pasar. Karena itu diperlukannya untuk mengidentifikasi segmen pasar mana yang paling cocok dan menarik untuk dapat dilayani dengan efektif. Dengan begitu strategi pemasaran yang dilakukan koperasi maestro lebih terarah pada satu segmen saja. 
Hal tersebut sesuai dengan teori, bahwasannya pembeli dari tiap segmen pasar menunjukkan perbedaan dalam motif, perilaku, dan kebiasaannya. Segmentasi pasar merupakan suatu proses membagi-bagi suatu pasar yang heterogen ke dalam kelompokkelompok pembeli atau konsumen yang memiliki ciri-ciri/sifat yang homogen dan dapat berarti bagi perusahaan. Segmen pasar tersebut akan dinilai dan dipertimbangkan untuk dipilih menjadi pasar sasaran yang dituju melalui usaha-usaha pemasaran perusahaan.

Dalam menentukan segmentasi pasar yang digunakan, koperasi maestro memilih menggunakan segmentasi demografi untuk mengelompokkan sasaran pasarnya. Koperasi maestro tidak serta merta begitu saja dalam memilih segmentasi pasarnya, ada beberapa faktor-faktor yang menjadi pertimbangan untuk memilih segmentasi demografi ini. Berikut faktor-faktor pemilihan segmentasi pasar koperasi maestro:

1. Resiko terhadap anggota golongan berpenghasilan tetap lebih kecil dibanding dengan anggota non golongan berpenghasilan tetap. Sedangkan untuk anggota non golongan yaitu wiraswasta, mereka tidak memiliki penghasilan yang tetap karena penghasilannya ditentukan oleh pengembangan yang didapat dari usaha yang dijalankan.

2. Tingkat pengembalian angsuran tepat waktu sesuai dengan jadwal, dikarenakan adanya kerjasama antara koperasi maestro dengan instansi terkait yang diwakili parawirausaha umkm. Sedangkan untuk non penghasilannya ditentukan oleh pengembangan yang didapat dari usaha yang dijalankan.

3. Persaingan tingkat margin di mikro dengan koperasi lain, dengan adanya program hasil karya para anggota dengan margin yang rendah koperasi maestro tidak bisa bersaing dengan koperasi lain karena adanya program- program dikoperasi tersebut.

4. Posisi persaingan yang lebih sedikit untuk non sehingga koperasi maestro lebih cepat untuk mendapatkan laba, berbeda dengan non yang jumlah pesaingnya begitu banyak.

5. Biaya untuk kegiatan pemasarannya lebih rendah karena non biasanya terdapat pada satu lingkup misalkan pada pemerintahan tangerang selatan, berbeda dengan non menyebar dimana mana.

6. Kemampuan koperasi maestro dengan jumlah marketing yang sedikit lebih mudah untuk menjangkau anggota dibanding anggota non, karena jumlah SDM yang kurang memadai dan proses analisa terhadap anggota non lebih rumit.

Hal ini sesuai dengan teori bahwasannya untuk menentukan segmentasi pasar harus memenuhi kriteria yaitu dapat diukur, dapat dijangkau, dapat dibedakan, dan dapat dilaksanakan. Maksudnya dapat diukur karena jumlah pegawai negeri di tangerang selatan yang banyak dan jumlah pesaingnya hanya sedikit. Lalu dapat dijangkau karena biaya pemasaran lebih rendah karena non biasanya hanya di satu lingkup saja maka mudah untuk dijangkau.

Meskipun resiko terhadap anggota non lebih kecil dan tingkat pengembalian angsuran tepat waktu sesuai dengan jadwal karena sudah bekerja sama dengan para wirausaha umkm, koperasi maestro juga tetap harus berhati- hati dalam memberikan pembiayaan pada calon anggota. Seperti anggota dengan sistem laba, sebelum memberikan pembiayaan koperasi maestro terlebih dahulu menganalisis dan mengecek apakah laba calon anggota tersebut masih atau cukup untuk membayar angsuran tiap bulan atau tidak. Dan untuk pembiayaan pada wirausaha P3 juga memakai sistem hasil pengembangan, karena koperasi melakukan kerjasama dengan lembaga tersebut. yayasan maestro pondaction.

Maka dengan memilih segmentasi pasar yang tepat yaitu segmentasi demografi maka akan memudahkan koperasi maestro dalam membedakan pasar dan memilah-milah kelompok konsumen/anggota mana yang berkualitas dan cocok dengan pemasaran dan produk-produk yang ada. Setelah dapat memahami dan menentukan nasabah dalam satu segmen, maka 
koerasi maestro dapat mengetahui siapa saja kompetitor yang berada dalam segmen tersebut dan mengetahui bagaimana dan apa strategi pemasaran yang dilakukan oleh kompetitor. Daftar kompetitor koperasi maestro yaitu koperasi mandiri, koperasi BMT serta koperasikoperasi lainnya ditangerang selatan.

Dengan begitu koperasi maestro harus mempersiapkan strategi pemasaran yang tepat agar dapat merebut perhatian anggota sehingga anggota lebih memilih bergabung dengan koperasi maestro dibanding dengan kompetitor/koperasi yang lain. Maka strategi pemasaran koperasi maestro akan menjadi lebih terarah, karena dengan pemasaran yang terarah menjadi kunci untuk berlangsungan dan kesuksesan usaha yang dijalani. Selain itu juga akan meningkatkan pelayanan koperasi maestro kepada anggota menjadi baik.

Hal ini juga sesuai dengan teori alasan koperasi untuk melakukan segmentasi pasar yaitu:

1. Semakin majunya kehidupan manusia, semakin heterogen masyarakat, semakin beragam kebutuhan dan selera masyarakat. Dan tidak mungkin ada suatu produk yang mampu memuaskan secara tepat seluruh lapisan masyarakat.

2. Semakin majunya perekonomian akan semakin banyak kompetitor yang harus dihadapi oleh perusahaan. Segmentasi akan mencegah perusahaan membuang sumber dayanya ditempat yang tidak tepat. Segmentasi akan membantu perusahaan untuk menyimpan sumber daya secara tepat ditempat yang tepat.

3. Segmentasi akan membentuk koerasi - ko[erasi untuk meraih keunggulan kompetitif atas kompetitornya melalui diferensiasi produk.

4. Suatu produk tidak akan mungkin memuaskan seluruh lapisan masyarakat, tetapi mungkin dapat memuaskan suatu kelompok masyarakat yang homogen. Dan segmentasi akan membantu perusahaan menemukan segmen-segmen yang dapat dilayani secara maksimal oleh perusahaan.

5. Untuk menghindari resiko koperasi maestro 2012

\section{KESIMPULAN DAN SARAN}

\section{Kesimpulan}

Untuk meningkatkan pemasaran, maka kesimpulan yang didapat dari kegiatan ini yaitu strategi pemasaran yang dilakukan meliputi berbagai strategi antara strategi produk, strategi harga, strategi lokasi, strategi promosi, strategi orang, strategi proses dan strategi bukti fisik.

Prosedur simpanan (Tabungan) yaitu mengisi formulir sesuai Kartu Identitas (KTP), kemudian menandatanganinya. Setelah itu formulir akan diperiksa dan jika sesuai dengan persyaratan akan disetujui, dan dilanjutkan mengisi slip sebagai setoran awal. Setelah melakukan setoran awal, akan dibuatkan buku tabungan dan setoran akan dimasukkan pada buku tabungan

\section{Saran}

Anggota Koperasi Maestro untu lebih meningkatkan strategi pemasaran, sehingga tujuan atau sasaran akan tercapai. Upaya peningkatan pengetahuan para anggota harus terus ditingkatan melalui sosialisasi yang lebih intensif lagi sehingga persepsi calon anggota terhadap produk dan sistem koperasi maestro juga semakin meningkat. Dengan peningkatan pemahaman tersebut akan secara langsung menciptkan peluang peningkatan usaha bagi anggota Koperasi Maestro. 


\section{DAFTAR PUSTAKA}

Al Arif, M. Nur Rianto. (2002) Dasar-Dasar Pemasaran Bank Syariah. Bandung: Alfabeta.

Arikunto, Suharsimi. (2010) Prosedur Penelitian Suatu Pendekatan Praktik. Jakarta: PT Renika Cipta.

Assauri, Sofyan. (2002) Manajemen Pemasaran Konsep, Dasar dan Strategi. Jakarta: Raja Grafindo Persada.

Fathoni, Abdurrahmat. (2011) Metodologi Penelitian dan Teknik Menyusun Skripsi. Jakarta: Rineka Cipta.

Hendro. (2011) Dasar-dasar Kewirausahaan Panduan bagi Mahasiswa untuk Mengenal, Memahami, dan Memasuki Dunia Bisnis. Jakarta: Erlangga.

Ikatan Bankir Indonesia dan Lembaga Sertifikasi Profesi Perbankan. (2015) Mengelola Bisnis Pembiayaan Bank Syariah. Jakarta: Gramedia Pustaka Utama.

IA Priatna et al. Menguatkan Ukhuwah Melalui Berbagi Antar Sesama Yang Terdampak Covid-19. Dedikasi PKM 1 (2020), 117-122

Kartono, Kartini. (1996) Pengantar Metodologi Riset Sosial. Bandung: CV. Mandar Maju.

Kountor, Rany. (2005) Metode Penelitian. Jakarta: Bumi Aksara.

Mujahidin, Andan Mahdi. (2014) Panduan Penilitian Praktis Untuk Menyusun Skripsi, Tesis, dan Disertasi. Bandung: Alfabeta.

Mursid, M. (2014). Manajemen Pemasaran. Jakarta: Bumi Aksara.

Priansa, Donny Juni. (2017) Perilaku Konsumen dalam Persaingan Bisnis Kontemporer. Bandung: Alfabeta.

Qurbani, D., Mardiana, S., \& Nugroho, R. D. (2020). Meningkatkan Minat Dan Potensi Generasi Milenial Khususnya Siswa-Siswi SMK Darussalam Untuk Memulai Bisnis Online Dengan Sistem Dropship. DEDIKASI PKM. 1 (3).

Sari, R., Suryani, N. L., Setiawan, R., Darmadi., \& Susanto, N. (2020). PENGELOLAAN SUMBER DAYA MANUSIA DALAM MENINGKATKAN PRODUKTIVITAS PADA UKM KELURAHAN PAGEDANGAN KABUPATEN TANGGERANGBANTEN. DEDIKASI PKM. 1 (3).

Soemitra, Andri. Bank dan Lembaga Keuangan Syari’ah. Jakarta: Kencana, (2009).

Sucipto, Agus. (2011) Studi Kelayakan Bisnis Analisis Integratif dan Studi Kasus. Malang: UIN-Maliki Press.

Sudaryono, (2016) Manajemen Pemasaran Teori dan Implikasi. Yogyakarta: ANDI.

Sudjana, Nana. (2011) Tuntunan Penyusunan Karya Ilmiah. Bandung: Sinar Baru Algensindo.

Suryabrata, Sumadi. (2008) Metodologi Penelitian. Jakarta: PT. Raja Grafindo Persada. https://agbersama.com/id-lamtim-info.htm 